\title{
The effect of biliary sphincterotomy on serum cholesterol levels in postcholecystectomy patients: A pilot study
}

\author{
Waleed M Alazmi MD, Evan L Fogel MD, James L Watkins MD, \\ Lee McHenry MD, Stuart Sherman MD, Glen A Lehman MD
}

WM Alazmi, EL Fogel, JL Watkins, L McHenry, S Sherman, GA Lehman. The effect of biliary sphincterotomy on serum cholesterol levels in postcholecystectomy patients: A pilot study. Can J Gastroenterol 2007;21(2):81-84.

BACKGROUND: Cholesterol, in the form of bile salts, is reabsorbed from the small intestine via the enterohepatic circulation. Biliary sphincterotomy increases the delivery of bile to the terminal ileum. If the absorptive capacity is exceeded, cholesterol excretion may increase, resulting in a decrease in serum cholesterol levels and improvement in serum lipid profiles.

AIM: To determine the effect of biliary sphincterotomy on serum cholesterol levels in patients without biliary obstruction.

PATIENTS AND METHODS: Postcholecystectomy patients with type III biliary sphincter of Oddi dysfunction (disabling pancreatobiliarytype pain with normal liver function tests and bile duct diameter) who underwent biliary sphincterotomy were identified retrospectively from the endoscopic retrograde cholangiopancreatography database. Baseline (pre-endoscopic retrograde cholangiopancreatography) laboratory investigations (including cholesterol) were obtained for all patients. The effect of sphincterotomy on total cholesterol levels was noted in all patients who returned for subsequent procedures (temporary pancreatic stent removal or evaluation of recurrent symptoms), and also in the subgroup of patients with baseline hypercholesterolemia (higher than $5.18 \mathrm{mmol} / \mathrm{L}$ ).

RESULTS: In the present pilot study, the performance of biliary sphincterotomy was associated with a reduction in total serum cholesterol levels in postcholecystectomy patients without biliary obstruction. This was statistically significant in patients with a baseline cholesterol level higher than $5.18 \mathrm{mmol} / \mathrm{L}$. A possible effect on lowand high-density lipoprotein concentrations was not evaluated. The influence of dietary changes and exercise were not accounted for. CONCLUSION: A prospective, controlled study involving a larger series of patients is required to determine whether biliary sphincterotomy lowers cholesterol levels and improves lipid profiles.

Key Words: Biliary sphincterotomy; Cholesterol levels;

Postcholecystectomy

Cardiovascular disease, including stroke, is the leading Cause of illness and death in the United States (US). There are an estimated 62 million people with cardiovascular disease and 50 million people with hypertension in the US alone (1). In 2000, approximately 946,000 deaths were attributable to cardiovascular disease, accounting for $39 \%$ of all deaths in the US (2). The relationship between elevated serum cholesterol levels and atherosclerosis was first noted in the 1930s in independent studies by Müller (3), and

\section{L'effet d'une sphinctérotomie biliaire sur les taux de cholestérol sériques de patients après une cholécystectomie : Un projet pilote}

HISTORIQUE : Le cholestérol, sous forme de sels biliaires, est réabsorbé de l'intestin grêle par la circulation entérohépatique. La sphinctérotomie biliaire accroît l'arrivée de bile à l'iléon terminal. Si la capacité absorptive est dépassée, l'excrétion cholestérinique peut augmenter et provoquer une diminution des taux de cholestérol sérique ainsi qu'une amélioration du profil lipidique sérique.

OBJECTIF : Déterminer l'effet d'une sphinctérotomie biliaire sur les taux de cholestérol sériques de patients ne présentant pas d'obstruction biliaire. PATIENTS ET MÉTHODOLOGIE : Les patients ayant subi une cholécystectomie à cause d'un dysfonctionnement Oddi du sphincter biliaire de type III (douleur pancréatobiliaire invalidante aux tests de fonction hépatique normale et diamètre du canal cholédoque) qui ont subi une sphinctérotomie biliaire ont été repérés rétrospectivement dans la base de données de cholangiopancréatographies rétrogrades endoscopiques. On a effectué des explorations (cholangiopancréatographie rétrograde préendoscopique) de départ en laboratoire (y compris le cholestérol) auprès de tous les patients. On a consigné l'effet de la sphinctérotomie sur les taux de cholestérol total chez tous les patients qui ont subi des interventions par la suite (ablation temporaire d'une endoprothèse pancréatique ou évaluation de symptômes récurrents) ainsi que dans le sous-groupe de patients ayant une hypercholestérolémie au départ (supérieure à $5,18 \mathrm{mmol} / \mathrm{L}$ ).

RÉSULTATS : Dans le présent projet pilote, le rendement de la sphinc térotomie biliaire s'associait à une réduction des taux de cholestérol sérique total après une cholécystectomie chez des patients ne présentant pas d'obstruction biliaire. Ces résultats étaient statistiquement significatifs chez les patients dont les taux cholestérinique de départ étaient supérieurs à 5,18 mmol/L. On n'en a pas évalué l'effet sur les concentrations de cholestérol à lipoprotéines de basse densité et de haute densité. On n'a pas tenu compte de l'influence des modifications au régime et de l'exercice.

CONCLUSIONS : Une étude contrôlée prospective portant sur une plus vaste série de patients s'impose pour déterminer si la sphinctérotomie biliaire réduit les taux de cholestérol et améliore les profils lipidiques.

Division of Gastroenterology and Hepatology, Department of Medicine, Indiana University Medical Center, Indianapolis, Indiana, USA

Correspondence: Dr Waleed M Alazmi, Division of Gastroenterology and Hepatology, Department of Medicine, Indiana University Medical Center,

550 North University Boulevard, Indianapolis, Indiana 46202, USA. Telephone 965-704-1221, fax 965-246-9628, e-mail walazmi@gmail.com Received for publication March 24, 2006. Accepted May 2, 2006 
Cholesterol is excreted in the bile in the form of bile salts (6). Once excreted from the liver, the bile salts flow into the duodenum via the common bile duct. A critical step in bile acid homeostasis is the reabsorption of bile salts in the intestinal lumen, which is a major determinant of the bile acid pool size and the activity of the bile acid synthesizing enzymes. Ninety per cent of bile salts are reabsorbed in the terminal ileum and returned to the liver via the portal vein (enterohepatic circulation). This bile salt pool completes this cycle six to nine times per day $(7,8)$.

It has long been accepted that the interruption of enterohepatic circulation, coupled with a decrease in the bile salt pool, may result in a net increase in cholesterol excretion with a corresponding decrease in serum cholesterol levels. On the other hand, a reduction in the bile salt pool, as seen in patients with biliary obstruction, may result in hypercholesterolemia. Patients with cholecystectomy and partial ileal bypass surgery may have increased excretion of bile salts. Cholecystectomy results in a net excretion of bile salts. The gallbladder acts as a reservoir for bile in the fasting state when bile is not needed for digestion of fat, and less bile reaches the small intestine. When the gallbladder is removed, the enterohepatic cycling of bile salts becomes continuous. A substantial portion of the bile salt pool is within the small bowel at all times. Every 90 min while fasting, the migrating myoelectric complex passes through the small intestine, sweeping intestinal contents, including much of the bile salt pool, rapidly passing the specialized absorptive sites in the ileum and moving into the colon. The local concentration of bile salts in the colon may exceed $3 \mathrm{mmol} / \mathrm{L}$ to $5 \mathrm{mmol} / \mathrm{L}$. This may inhibit colonic fluid and electrolyte absorption, and accelerate transit, resulting in postcholecystectomy diarrhea (9-11). However, more recent studies $(12,13)$ on the effect of cholecystectomy on bile salt metabolism have found no increase in bile acid synthesis. By reducing the capacity for bile salt reabsorption, partial ileal bypass surgery also results in a decrease in serum cholesterol levels. The results of the Program on the Surgical Control of the Hyperlipidemias (POSCH) trial (14), which involved a total of 838 patients with myocardial infarction, were promising. A five-year follow-up of the study revealed significant reductions, up to $24 \%$ in total cholesterol levels, in patients who underwent partial ileal bypass operation compared with controls $(14,15)$.

The sphincter of Oddi is a major regulator of bile flow. Biliary sphincterotomy interrupts the sphincter function, rendering it incapable of regulating bile flow. This results in a continuous flow of bile salts to the small intestine. If the absorptive capacity of the terminal ileum is exceeded, a proportion of bile salts may effectively leave the enterohepatic circulation, which may result in increased excretion of cholesterol in the feces.

Therefore, we hypothesize that the performance of a biliary sphincterotomy in patients with a nonobstructed biliary tree leads to a reduction in serum cholesterol levels.

\section{PATIENTS AND METHODS}

Postcholecystectomy patients who were referred to the Indiana University Medical Center (Indiana, USA) for consideration of therapeutic endoscopic retrograde cholangiopancreatography (ERCP) for investigation and management of type III sphincter of Oddi dysfunction (SOD) were identified using the ERCP database. These patients had chronic abdominal pain believed to be of pancreatobiliary origin, with normal serum liver and pancreatic enzymes, and normal calibre (nondilated) pancreatic and bile ducts. Patients who underwent biliary sphincterotomy as treatment for manometry-documented SOD and who had follow-up serum cholesterol levels available were included. The exclusion criteria included those individuals who were younger than 18 years of age, had mental disabilites, were unable to obtain informed consent, were taking a lipid-lowering agent, had a cholecystectomy less than one year before study entry and were prisoners. As per the routine for all ERCP patients before ERCP, patients underwent a complete history and physical examination. Laboratory tests included complete blood counts, comprehensive metabolic profiles, serum cholesterol, serum amylase and lipase level measurement. For all patients who returned for a subsequent procedure (for temporary pancreatic stent removal or evaluation of recurrent symptoms), the effect of biliary sphincterotomy on total cholesterol was noted. The Institutional Review Board of Indiana University - Purdue University of Indianapolis (Indianapolis, USA) approved the present study.

\section{Statistical analysis}

Baseline demographic and clinical characteristics, including age, sex, past medical and surgical history, review of systems and physical examination findings, and clinical laboratory parameters, were tested for differences between treatment groups using the $\chi^{2}$ test for categorical variables and Student's $t$ test for continuous variables. Analysis of covariance models, treating the time points as fixed, were used to compare the times for differences in cholesterol levels while adjusting for covariates and were used to correlate the multiple measurements made over time for each patient. A paired $t$ test was used to calculate the differences between pre- and postsphincterotomy cholesterol levels, along with 95\% CIs for the differences. All significant testing was two-sided, with a threshold for statistical significance of $\mathrm{P}<0.05$.

\section{RESULTS}

Between June 1998 and October 2000, 321 patients underwent ERCP for suspected type III SOD. Sixty-one patients were included in the final analysis. There were 56 (92\%) women and $54(88 \%)$ Caucasians. The mean age was 42 years (range 18 to 71 years), mean time between pre- and postbiliary sphincterotomy cholesterol levels was 129.5 days (range seven to 844 days), and the mean cholesterol levels before and after biliary sphincterotomy was $5.22 \pm 1.12 \mathrm{mmol} / \mathrm{L}$ (range $3.0 \mathrm{mmol} / \mathrm{L}$ to $8.57 \mathrm{mmol} / \mathrm{L}$ ) and $5.02 \pm 1.14 \mathrm{mmol} / \mathrm{L}$ (range $2.69 \mathrm{mmol} / \mathrm{L}$ to $7.82 \mathrm{mmol} / \mathrm{L}$ ), respectively. The absolute mean difference between pre- and postsphincterotomy cholesterol levels was $-0.19 \mathrm{mmol} / \mathrm{L}(95 \%$ CI $-0.38 \mathrm{mmol} / \mathrm{L}$ to $0 \mathrm{mmol} / \mathrm{L})$. Forty-eight (78.7\%) patients had their cholesterol levels tested 30 days or more after biliary sphincterotomy. In this group, the absolute mean difference between pre- and postsphincterotomy cholesterol levels was $-0.16 \mathrm{mmol} / \mathrm{L}$ (95\% CI $-0.38 \mathrm{mmol} / \mathrm{L}$ to $0.07 \mathrm{mmol} / \mathrm{L})$. Thirty patients $(49.2 \%)$ had baseline hypercholesterolemia with a cholesterol level greater than or equal to $5.18 \mathrm{mmol} / \mathrm{L}$, while the absolute mean difference between pre- and postsphincterotomy cholesterol levels was $-0.36 \mathrm{mmol} / \mathrm{L} \quad(95 \%$ CI $-0.64 \mathrm{mmol} / \mathrm{L}$ to $-0.09 \mathrm{mmol} / \mathrm{L})$. Twenty of these patients had their cholesterol levels tested 30 days or more after biliary sphincterotomy. The absolute mean difference between pre- and postsphincterotomy cholesterol levels in this group was $-0.54 \mathrm{mmol} / \mathrm{L}$ (95\% CI 


\section{TABLE 1}

The effect of biliary sphincterotomy on serum cholesterol levels in postcholecystectomy patients

\begin{tabular}{|c|c|c|c|c|c|c|}
\hline Patient group & $\begin{array}{l}\text { Time between } \\
\text { pre- and post-ES } \\
\text { cholesterol levels }\end{array}$ & $\mathbf{n}$ & $\begin{array}{l}\text { Mean days between } \\
\text { pre- and post-ES } \\
\text { cholesterol levels }\end{array}$ & $\begin{array}{c}\text { Mean pre-ES } \\
\text { cholesterol levels } \\
(\mathrm{mmol} / \mathrm{L})\end{array}$ & $\begin{array}{l}\text { Absolute mean difference } \\
\text { between pre- and post-ES } \\
\text { cholesterol levels (mmol/L) }\end{array}$ & $95 \% \mathrm{Cl}$ \\
\hline All & No time restriction & 61 & 129.50 & 5.22 & -0.19 & -0.38 to 0 \\
\hline \multirow[t]{2}{*}{ Cholesterol $>5.18 \mathrm{mmol} / \mathrm{L}$} & No time restriction & 30 & 127.70 & 6.10 & -0.36 & -0.64 to -0.09 \\
\hline & More than 30 days & 20 & 181.70 & 6.19 & -0.54 & -0.87 to $-0.22^{*}$ \\
\hline
\end{tabular}

*Statistically significant $(P<0.05)$. ES Endoscopic sphincterotomy

$-0.87 \mathrm{mmol} / \mathrm{L}$ to $-0.22 \mathrm{mmol} / \mathrm{L}$ ), which was statistically significant. These results are shown in Table 1.

\section{DISCUSSION}

CAD is a major cause of morbidity and mortality in developed countries, and dyslipidemia is one of its major causes. A meta-analysis of 38 primary and secondary prevention trials found that for every 10\% reduction in serum cholesterol levels, CAD mortality was reduced by $15 \%$ and total mortality risk was reduced by $11 \%$ (16). There has been ample research on strategies used to lower serum cholesterol levels, and pharmacotherapy has been the main strategy pursued. Several classes of agents are now available with documented efficacies to reduce serum cholesterol levels. The most widely prescribed class of agents is the hydroxymethylglutaryl-coenzyme A reductase inhibitors. These agents are expensive and have to be taken daily. The average monthly cost, depending on the agent and dose used, ranges from US $\$ 14.00$ to US $\$ 139.00$ (17). Medical therapy for hypercholesterolemia is often lifelong and is associated with a spectrum of adverse effects. These include allergic reactions, hepatitis and myositis (18-26). These adverse events may be extremely severe, eventually leading to cessation of drug intake. Therefore, alternative methods of lowering serum cholesterol levels are welcomed.

The present pilot study tests the hypothesis of reducing serum cholesterol levels after biliary sphincterotomy in postcholecystectomy patients with abdominal pain and a nonobstructed biliary tree. While there was a trend to reduce cholesterol levels in all patients, there was a statistically significant reduction in the serum cholesterol levels among high-risk patients with baseline cholesterol levels higher than $5.18 \mathrm{mmol} / \mathrm{L}$. The mean effect of an $8 \%$ reduction was seen among those patients who had their cholesterol levels tested at 30 days or more after biliary sphincterotomy. Biliary sphincterotomy may result in a larger pool of bile salts presented to the terminal ileum, leading to an overflow phenomenon. We hypothesize that this increased the excretion of cholesterol in the feces.

To exclude possible confounding effects, all patients who were on lipid-lowering agents were excluded from the present study. Furthermore, no patient noted to have baseline hypercholesterolemia was subsequently started on a lipidlowering agent before repeat evaluation. Earlier studies have suggested a possible effect of recent cholecystectomy (within a few months) on serum cholesterol levels. However, more recent studies $(12,13)$ have demonstrated that cholecystectomy causes no changes in bile acid pool composition, and thus, has no adverse effects on bile acid metabolism in the long-term. To exclude this potential confounding variable, we excluded all patients who had had their gallbladder removed within one year before study entry. In addition, only postcholecystectomy patients were included to have a more homogeneous study population.

Other important confounding factors were not accounted for in the present pilot study. First, because all our patients had type III SOD with chronic abdominal pain, dietary habits may be expected to change after endoscopic therapy, which may affect cholesterol levels. Dietary intake may increase in patients with relief of symptoms following sphincter therapy, while intake may remain the same in those who failed to respond to sphincter therapy. Second, exercise patterns could change following therapy, also affecting cholesterol levels. Finally, low- and high-density lipoproteins and triglycerides were not measured in the present study. The concentrations of low- and high-density lipoproteins and triglycerides are known to be paramount in assessing a patient's risk for cardiovascular disease.

The adaptive changes in the remaining intestine after intestinal resection have been extensively studied in animal models and to a limited extent, in humans as well $(27,28)$. The ileum attains the morphological characteristics of the jejunum, with taller villi and deeper crypts (29). With time, there is also an increase in ileal diameter and length. The result of these changes is an increase in absorptive capacity per unit length (30). In humans, the adaptive changes may take one to two years to fully develop (31). In our study, the mean follow-up was approximately six months in the group in which the maximum effect was noticed. While this decrease in cholesterol level is encouraging, intestinal adaptation could result in the loss of this effect with longer follow-up time (one to two years).

Biliary sphincterotomy is an invasive procedure performed by gastrointestinal endoscopists and is not without complications. In a study by Freeman et al (32), 9.8\% of patients undergoing endoscopic sphincterotomy had a complication, including pancreatitis $(5.4 \%)$, bleeding $(2 \%)$, cholangitis (1\%) and perforation (less than $0.5 \%)$. The incidence of late complications of biliary sphincterotomy in studies with extended follow-up (five to 10 years or more) ranges from $10 \%$ to $24 \%$ (33). These late complications include stenosis of the sphincterotomy site, cholangitis and recurrent choledocholithiasis. Most of the late complications of ERCP can be managed by endoscopic therapy. While it is assumed that an intact sphincter mechanism prevents duodenal-pancreatobiliary reflux, there is no support in the literature to suggest that biliary sphincterotomy alone in patients with a normal biliary tree (with no stent placement) increases infections or other complications 


\section{CONCLUSIONS}

The present study suggests that biliary sphincterotomy results in a statistically significant reduction of serum cholesterol levels in postcholecystectomy patients with type III SOD and baseline hypercholesterolemia (levels higher than $5.18 \mathrm{mmol} / \mathrm{L}$ ). The

\section{REFERENCES}

1. National Heart, Lung, and Blood Institute. Morbidity \& Mortality: 2004 Chartbook on Cardiovascular, Lung, and Blood Diseases. <http://www.nhlbi.nih.gov/resources/docs/cht-book.htm> (Version current at January 12, 2007).

2. National Heart, Lung, and Blood Institute. Fact Book Fiscal Year 2005. <http://www.nhlbi.nih.gov/about/factpdf.htm>

(Version current at January 12, 2007).

3. Müller C. Xanthomata, hypercholesterolemia, angina pectoris. Acta Med Scand 1939;89:75-84.

4. Thannhauser SJ, Magendantz $\mathrm{H}$. The different clinical groups of xanthomatous disease: A clinical physiological study of 22 cases. Ann Intern Med 1938;11:1662-746.

5. Kannel WB, Castelli WP, Gordon T, McNamara PM. Serum cholesterol, lipoproteins, and the risk of coronary heart disease. The Framingham study. Ann Intern Med 1971;74:1-12.

6. Knopp RH. Drug treatment of lipid disorders. N Engl J Med 1999;341:498-511.

7. Xu G, Shneider BL, Shefer S, et al. Ileal bile acid transport regulates bile acid pool, synthesis, and plasma cholesterol levels differently in cholesterol-fed rats and rabbits. J Lipid Res 2000;41:298-304.

8. Kullak-Ublick GA, Stieger B, Meier PJ. Enterohepatic bile salt transporters in normal physiology and liver disease. Gastroenterology 2004;126:322-42.

9. Gelbmann CM, Schteingart CD, Thompson SM, Hofmann AF, Barrett KE. Mast cells and histamine contribute to bile acid-stimulated secretion in the mouse colon. J Clin Invest 1995;95:2831-9.

10. Fort JM, Azpiroz F, Casellas F, Andreu J, Malagelada JR. Bowel habit after cholecystectomy: Physiological changes and clinical implications. Gastroenterology 1996;111:617-22.

11. Arlow FL, Dekovich AA, Priest RJ, Beher WT. Bile acid-mediated postcholecystectomy diarrhea. Arch Intern Med 1987;147:1327-9.

12. Kullak-Ulblick GA, Paumgartner G, Berr F. Long-term effects of cholecystectomy on bile acid metabolism. Hepatology 1995;21:41-5.

13. Berr F, Stellaard F, Pratschke E, Paumgartner G. Effects of cholecystectomy on the kinetics of primary and secondary bile acids. J Clin Invest 1989;83:1541-50.

14. Buchwald H, Varco RL, Matts JP, et al. Effect of partial ileal bypass surgery on mortality and morbidity from coronary heart disease in patients with hypercholesterolemia. Report of the Program on the Surgical Control of the Hyperlipidemias (POSCH). N Engl J Med 1990;323:946-55

15. Moghadasian MH, Frohlich JJ, Saleem M, Hong JM, Qayumi K, Scudamore CH. Surgical management of dyslipidemia: Clinical and experimental evidence. J Invest Surg 2001;14:71-8.

16. Gould AL, Rossouw JE, Santanello NC, Heyse JF, Furberg CD. Cholesterol reduction yields clinical benefit: Impact of statin trials. Circulation 1998;97:946-52. mean reduction was $8 \%$ over a mean follow-up period of approximately six months. A prospective, controlled study involving a larger series of patients with longer follow-up time is required to determine whether biliary sphincterotomy lowers serum cholesterol levels and improves lipid profiles.

17. Three new drugs for hyperlipidemia. Med Lett Drugs Ther 2003;45:17-9.

18. Rosenson RS. Current overview of statin-induced myopathy. Am J Med 2004;116:408-16.

19. Downs JR, Clearfield M, Weis S, et al. Primary prevention of acute coronary events with lovastatin in men and women with average cholesterol levels: Results of AFCAPS/TexCAPS. Air Force/Texas Coronary Atherosclerosis Prevention Study. JAMA 1998;279:1615-22.

20. Randomised trial of cholesterol lowering in 4444 patients with coronary heart disease: The Scandinavian Simvastatin Survival Study (4S). Lancet 1994;344:1383-9.

21. Heart Protection Study Collaborative Group. MRC/BHF Heart Protection Study of cholesterol lowering with simvastatin in 20536 high-risk individuals: A randomized placebo-controlled trial Lancet 2002;360:7-22.

22. Tonolo G, Melis MG, Formato M, et al. Additive effects of simvastatin beyond its effects on LDL cholesterol in hypertensive type II diabetic patients. Eur J Clin Invest 2000;30:980-7.

23. Smith CC, Bernstein LI, Davis RB, Rind DM, Shmerling RH. Screening for statin-related toxicity: The yield of transaminase and creatine kinase measurements in a primary care setting. Arch Intern Med 2003;163:688-92.

24. Weismantel D, Danis P. Clinical inquiries. What laboratory monitoring is appropriate to detect adverse drug reactions in patients on cholesterol-lowering agents? J Fam Pract 2001;50:927-8.

25. Gotto AM Jr. Safety and statin therapy: Reconsidering the risks and benefits. Arch Intern Med 2003;163:657-9.

26. Ballantyne CM, Corsini A, Davidson MH, et al. Risk for myopathy with statin therapy in high-risk patients. Arch Intern Med 2003; 163:553-64.

27. Williamson RC. Intestinal adaptation (first of two parts). Structural, functional and cytokinetic changes. N Engl J Med 1978;298:1393-402.

28. Williamson RC. Intestinal adaptation (second of two parts). Mechanisms of control. N Engl J Med 1978;298:1444-50.

29. Appleton GV, Bristol JB, Williamson RC. Proximal enterectomy provides a stronger systemic stimulus to intestinal adaptation than distal enterectomy. Gut 1987;28:165-8.

30. Chaves M, Smith MW, Williamson RC. Increased activity of digestive enzymes in ileal enterocytes adapting to proximal small bowel resection. Gut 1987;28:981-7.

31. Dowling RH. Small bowel adaptation and its regulation. Scand J Gastroenterol Suppl 1982;74:53-74

32. Freeman ML, Nelson DB, Sherman S, et al. Complications of endoscopic biliary sphincterotomy. N Eng J Med 1996;335:909-18.

33. Bergman JJ, Van der Mey S, Rauws EA, et al. Long-term follow-up after biliary sphincterotomy for bile duct stones in patients younger than 60 years of age. Gastrointest Endosc 1996;44:643-9. 


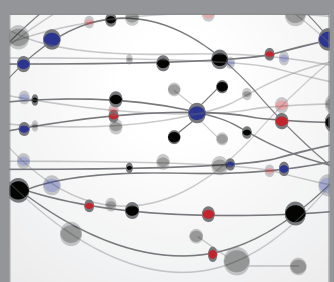

The Scientific World Journal
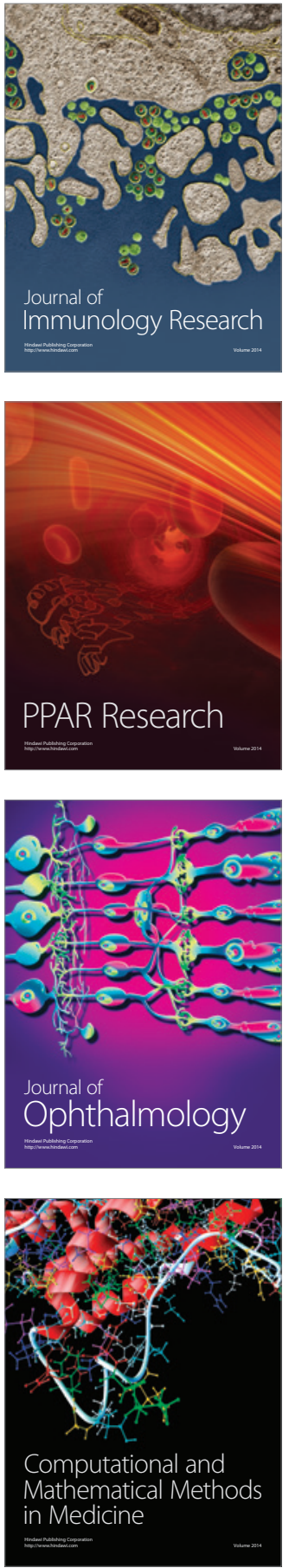

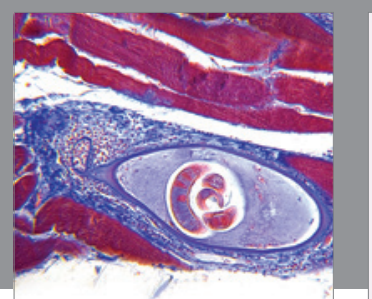

Gastroenterology Research and Practice

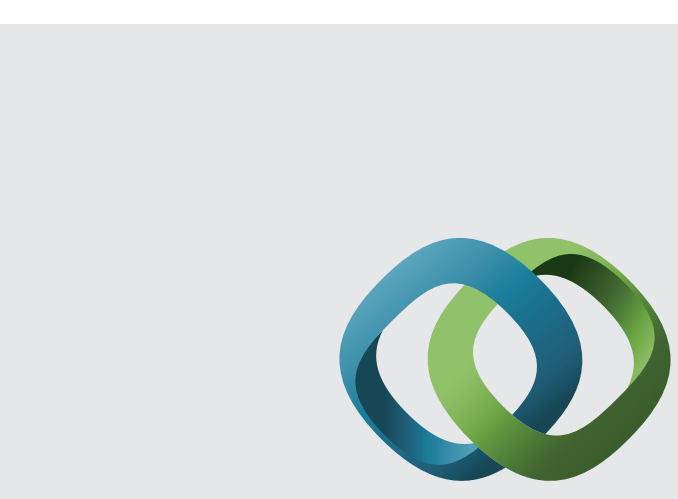

\section{Hindawi}

Submit your manuscripts at

http://www.hindawi.com
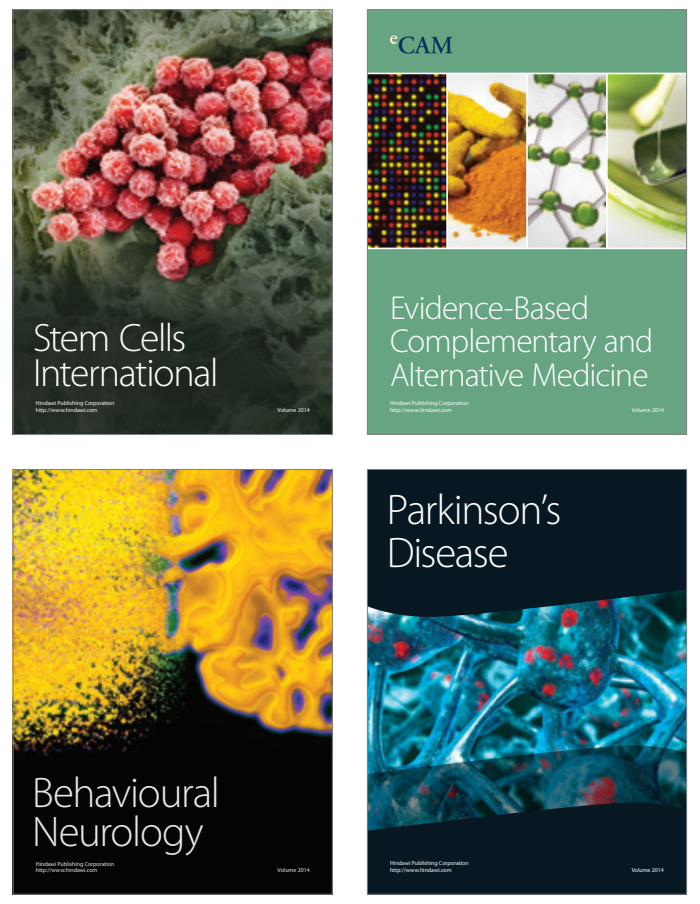
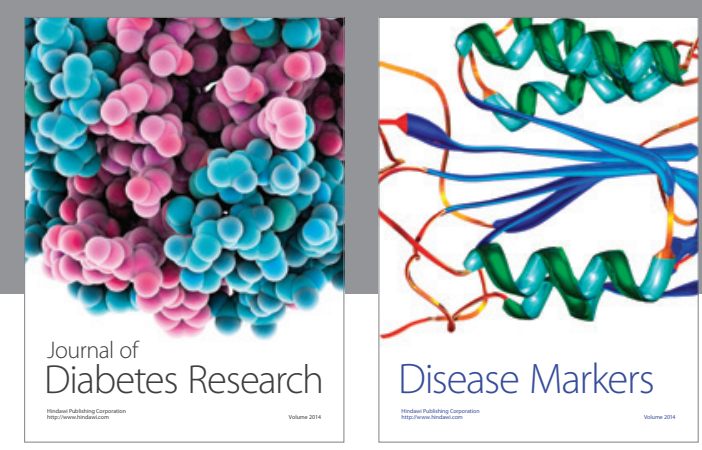

Disease Markers
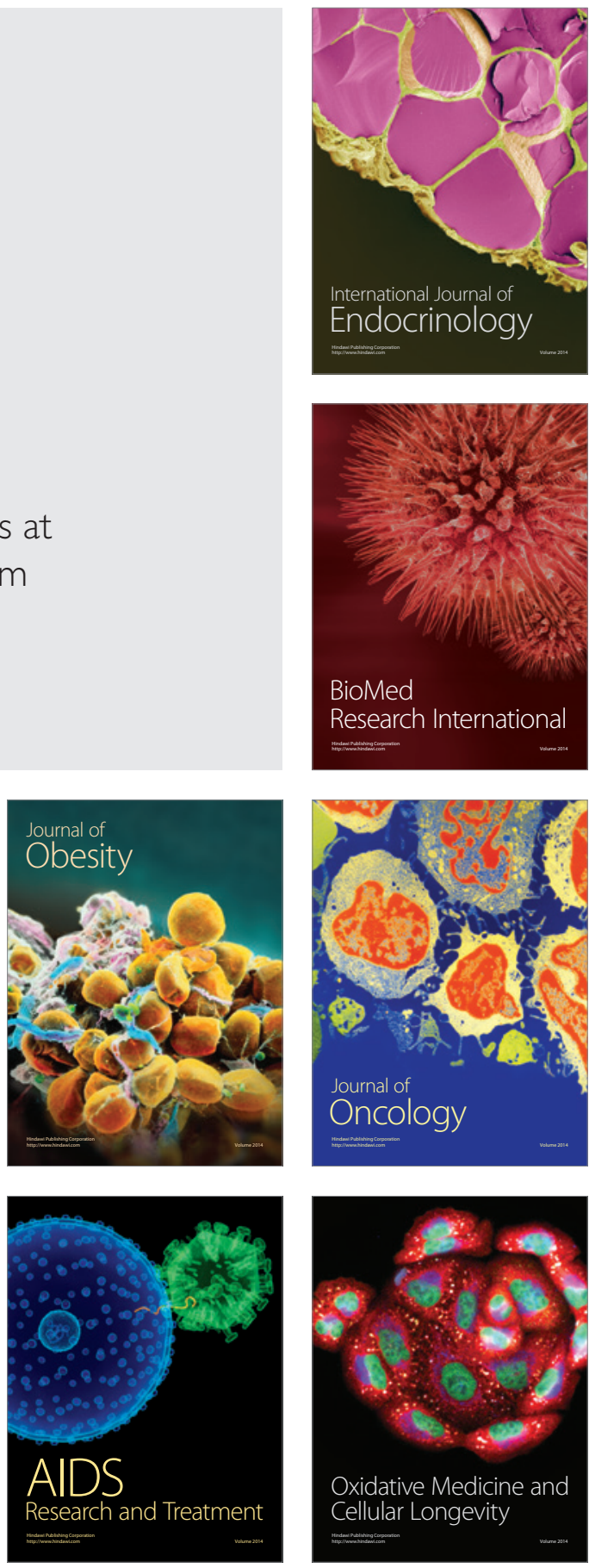